\title{
Evaluasi Program Kelompok Usaha Bersama (KUBE) di Kecamatan Batu Kota Batu
}

\author{
Bagus Nugroho Putro ${ }^{1}$, Saiman², Iradhad Taqwa Sihidi ${ }^{3 *}$ \\ ${ }^{1}$ Ilmu Pemerintahan, Universitas Muhammadiyah Malang, Indonesia \\ ${ }^{2}$ Ilmu Pemerintahan, Universitas Muhammadiyah Malang, Indonesia \\ ${ }^{3}$ Ilmu Pemerintahan, Universitas Muhammadiyah Malang, Indonesia
}

\begin{abstract}
The implementation of the Joint Business Group (KUBE) program in the Batu City Batu District began in 2015 and is still ongoing today. Until now, there are around 21 active KUBE groups in this sub-district and 21 inactive KUBE groups (the most in Kota Batu). This research then aims to evaluate the KUBE program in the sub-district of Batu, Batu City. This research uses a qualitative model with a descriptive type. Data collection techniques through observation, interviews, and documentation. The subjects were interviewed by the Batu City Social Service, KUBE assistants, and KUBE administrators in Batu District. The results of this study indicate that the KUBE program has not been running according to what is targeted by the Batu City Social Service. The effectiveness criteria are still not fulfilled because KUBE members are not actively producing. Likewise, with the efficiency criteria, KUBE members are still confused in managing funds, and the products that are sold sometimes do not run out. The criteria for the adequacy of the results obtained are not sufficient for daily needs. The criteria for equitable distribution of benefits have been felt, but not for the results. The responsiveness criterion is still lack of mentoring and monitoring and evaluation from the mentor. The criteria for the accuracy of the aid distribution process are good and precise, but not many KUBE has carried out independent graduations.
\end{abstract}

Keywords: batu city, joint business group (kube), policy evaluation, welfare

\begin{abstract}
Abstrak
Pelaksanaan program Kelompok Usaha Bersama (KUBE) yang ada di Kecamatan Batu Kota Batu dimulai sejak tahun 2015 dan masih berjalan sampai sekarang. Sampai saat ini di Kecamatan tersebut tercatat Jumlah KUBE yang masih aktif ada sekitar 21 kelompok dan jumlah KUBE yang tidak aktif mencapai 21 kelompok (terbanyak di Kota Batu). Penelitian ini selanjutnya bertujuan melakukan evaluasi pada program KUBE di kecamatan Batu Kota Batu. Adapun penelitian ini menggunakan model kualitatif dengan jenis deskriptif. Teknik pengumpulan data melalui observasi, wawancara, dan dokumentasi. Subyek wawancara Dinas Sosial Kota Batu, pendamping KUBE, serta pengurus KUBE yang ada di Kecamatan Batu. Hasil penelitian ini menunjukan program KUBE belum berjalan sesuai dengan apa yang ditargetkan Dinas Sosial Kota Batu. Kriteria efektifitas masih belum terpenuhi karena anggota KUBE tidak aktif berproduksi. Demikian dengan kriteria efisiensi, anggota KUBE masih kebingungan dalam pengeloaan dana dan hasil produksi yang dijual terkadang tidak habis. Kriteria kecukupan hasil yang didapatkan belum mencukupi kebutuhan sehari-hari. Kriteria pemerataan segi manfaat sudah dirasakan, tetapi untuk hasil belum. Kriteria responsifitas masih kurangnya pendampingan dan monef dari pendamping. Kriteria ketepatan proses penyaluran bantuan sudah baik dan tepat tetapi belum banyak KUBE yang melakukan graduasi mandiri.
\end{abstract}

Kata Kunci: evaluasi kebijakan, kelompok usaha bersama (kube), kesejahteraan, kota batu

\footnotetext{
*iradhad@umm.ac.id
}

DOI: https://doi.org/10.26618/kjap.v6i3.4210 


\section{PENDAHULUAN}

Kemiskinan adalah sebuah problematika yang sangat sulit untuk dihilangkan dalam permasalahan sosial masyarakat. Kemiskinan merupakan kondisi kekurangan atau tidak memiliki dalam berbagai aspek seperti sandang, pangan, papan, pendidikan, dan kesehatan. Kemiskinan merupakan masalah struktural yang salah satunya karena minimnya partisipasi masyarakat dalam pembangunan (Sitepu, 2016, Boone \& Roets, 2018) dan lingkungan sosial yang tidak mendukung (Zhou, Guo, \& Liu, 2019). Pada dasarnya kemiskinan dipetakan menjadi dua kategori yaitu kemiskinan relatif dan kemiskinan absolut. Kemiskinan absolut adalah sebuah kondisi kemiskinan yang mana kondisi tingkat penghasilan seseorang tidak bisa untuk mencukupi segala kebutuhan pokok sepeti sandang, pangan, papan, pendidikan, serta kesehatan. Kemiskinan relatif adalah kondisi kemiskinan yang dimana kondisi masyarakat atau pribadi menganggap dirinya sebagai masyarakat miskin karena latar belakang seperti melihat orang lain memiliki perekonomian lebih dibanding dengan dirinya (Ras, 2013).

Kemiskinan sendiri pada negara berkembang merupakan masalah yang cukup rumit, meskipun beberapa negara berkembang telah berhasil melaksanakan pembangunan dalam hal produksi dan pendapatan nasional. Kondisi kemiskinan suatu negara atau daerah juga merupakan cerminan dari tingkat kesejahteraan penduduk yang tinggal pada daerah tersebut. Berdasarkan Undang-Undang RI No 11 Tahun 2009 tentang Kesejahteraan Sosial dan ditindaklanjuti Perpres No 15 Tahun 2010 tentang Percepatan Penanggulangan Kemiskinan dan UU RI No 13 tahun 2011 tentang Penangganan Fakir Miskin dalam rangka Penanggulangan Kemiskinan. Kementrian Sosial sebagai instansi pemerintah yang dimana memiliki tugas pemerintahan dan pembangunan dalam bidang kesejahteraan sosial, merencanakan program pemberdayaan fakir miskin melalui pendekatan Kelompok Usaha Bersama (KUBE) (Widayanti \& Hidayatulloh, 2015).

Penanganan fakir miskin adalah sebuah upaya yang terarah, terpadu, dan berkelanjutan yang dilakukan oleh pemerintah. Peran Pemerintah disini membuat kebijakan berdasarkan permasalahan dari kondisi masyarakat setempat dan juga masyarakat berhak membuat keputusan pula. Berdasarkan kebijakan tersebut dilakukan program kegiatan dalam pemberdayaan kelembagaan masyarakat, Peningkatan kapasitas fakir miskin untuk mengembangkan kemampuan berusaha, 
jaminan, serta perlindungan sosial untuk memberikan rasa aman bagi fakir miskin, kemitraan dan kerja sama antar pemangku kepentingan, dan koordinasi antara Kementrian dan Pemerintah.

Keterlibatan masyarakat dalam pembuatan suatu kebijakan sangat penting (Hadi, Asworo \& Sihidi, 2020). Masyarakat juga menjadi pelaku terpenting dalam suatu pembangunan dan pemerintah harus mengontrol, melindungi, mendampingi serta membina masyarakat dalam melakukan suatu tidankan. KUBE lahir dari keresahan masyarakat terkait dengan kemiskinan yang ini menjadi suatu permasalahan sosial yang masih menjadi suatu hal yang kompleks dan krusial di Kota Batu. KUBE adalah upaya memutus mata rantai kemiskinan generasi selanjutnya. Sebab kemiskinan yang tidak mampu diurai dengan baik berkorelasi positif pada kecilnya kesejahteraan generasi selanjutnya (anak-anak) (Chaudry \& Wimer, 2016). KUBE bertujuan meningkatkan pendapatan keluarga yang tentu saja secara empiris mampu menurunkan angka kemiskinan (Kwasi, 2017).

Kelompok Usaha Bersama (KUBE) adalah wadah berkumpul masyarakat miskin yang memiliki kesamaan tujuan dalam membangun kesejahteraan lewat kelompok. Dengan pembentukan program tersebut kelompok masyarakat yang kurang mampu dapat berpartisipasi dalam melakukan kegiatan pembangunan perekonomian sehingga masyarakat akan mampu memenuhi kebutuhan hidupnya. Dengan demikian hal tersebut mampu untuk mensejahterakan masyarakat terkhusus dengan anggota, menggerakkan roda perekonomian nasional pada masyarakat lapisan bawah, mengembangkan jiwa kewirausahaan, mengembangkan sistem jaringan usaha, meningkatkan kemandirian ekonomi rakyat, serta meningkatkan pendapatan.

Adapaun pelaksanaan berdasarkan pada indikator-indikator keberhasilan yang terukur akan membantu organisasi dalam mewujudkan percapaian target-target tersebut (Pedoman KUBE Tahun 2011). Tujuan yang menjadi pencapaian dalam KUBE adalah untuk mempercepat pengentasan kemiskinan dengan cara meningkatkan kemampuan dalam hal berusaha pada para anggota KUBE melalui kelompok yang sudah dibentuk, peningkatan dalam pendapatan, pengembangan usaha, serta peningkatan kepedulian antar anggota KUBE dengan masyarakat sekitar. Jadi secara umum KUBE ini dibentuk bertujuan untuk meningkatkan kualitas taraf hidup dan kesejahteraan sosial sebagai benyuk penanggulangan kemiskinan.

Dengan kelompok KUBE ini diharapkan masyarakat dapat 
berwirasusaha. Dalam konteks pengentasan kemiskinan berwirausaha menjadi salah kunci strategis karena terbukti mampu meningkatkan pendapatan masyarakat (Sutter, Bruton, \& Chen, 2018). Program KUBE ini akan memberikan bantuan dana yang akan digunakan sebagai modal dalam membentuk usaha ekonomi produktif (UEP). KUBE terdiri dari masyarakat miskin yang nantinya akan membentuk kelompok untuk melakukan sebuah kegiatan usaha ekonomi produktif. Dalam pembentukan kelompok KUBE akan beranggotakan 10 orang perkelompokanya. Proses pembentukan harus sesuai dengan ketentuan-ketentuan yang telah diatur dalam keputusan Meteri Sosial Nomor 84/HUK/2010 terkait dengan Organisasi dan Tata Kerja Kementerian Sosial dan telah dijelaskan dengan detail dalam juklis pelaksanaan. Pemerintah juga menerapkan beberapa kebijakan salah satunya adalah kebijakan satu data dalam penanggulangan kemiskinan melalui Basis Data Terpadu (BDT).

Kota Batu merupakan salah satu Kota yang berada di Jawa Timur yang telah menjalankan Program Kelompok Usaha Bersama (KUBE) mulai tahun 2015. Kota Batu memang memiliki berbagai destinasi wisata yang sangat beragam. Tetapi masalah terkait dengan kemiskinan merupakan salah satu permasalahan klasik yang terjadi disetiap daerah. Jumlah penduduk miskin di Kota Batu menurut data dari BPS pada tahun 2018 adalah 7.980 jiwa dari total keseluruhan masyarakat yang ada di Kota Batu berjumlah 205.788 jiwa dengan presentase kemiskinan 3,89\%. Meskipun presentase kemiskinan menurun setiap tahunya, tetapi program pengentasan kemiskinan perkotaan belum sepenuhnya teratasi dengan baik. Salah satunya adalah Program kelompok Usaha Bersama (KUBE) yang merupakan salah satu program yang dikeluarkan oleh Kementerian Sosial RI yang selanjutnya program ini dilaksanakan oleh Dinas Sosial yang ada di daerah masing-masing.

Pelaksanaan program KUBE di Kecamatan Batu pertama kali dimulai pada tahun 2015. Pada saat itu ada sebanyak 3 KUBE dengan jumlah anggota 30 orang. Pada tahun pertama pelaksanaan KUBE terdapat jenis usaha yang berbeda seperti produksi kripik mbote, kue tradisional, dan usus krispi. Jumlah bantuan yang diterima oleh setiap kelompokya sebesar Rp. 20.000.000 yang di gunakan untuk mengembangkan usaha ekonomi produktif sesuai dengan yang direncanakan pada awal pembentukan kelompok.

Pada tahun 2019 ini jumlah keseluruhan Kelompok Usaha Bersama (KUBE) yang ada di Kota Batu mencapai 45 kelompok yang tersebar diseluruh Kota 
Batu. Kecamatan Batu berjumlah 21 KUBE, Kecamatan Bumiaji 10 KUBE, dan Kecamatan Junrejo 14 KUBE. Keseluruhan kelompok ini sudah memiliki berbagai jenis usaha yang sudah berkembang dan berbeda pula. Saat ini berbagai jenis usaha yang telah berjalan sudah merambah dipusat oleh-oleh bahkan juga sudah ada yang bekerja sama dengan salah satu hotel yang ada di Kota Batu.

Pelaksanaan monitoring dan evalausi dilakukakn oleh Pendamping setiap satu kali dalam sebulan yang bertujuan untuk memantau serta mengevaluasi apa saja yang harus dilakukan perbaikan dalam produksi. Seiring berjalannya waktu mulai tahun 2015 sampai tahun 2019, pelaksanaan program KUBE ini banyak yang tidak berproduksi dan akhirnya kelompok usaha tersebut bubar. Keseluruhan jumlah kelompok yang tidak aktif atau bubar di Kecamatan Batu mencapai 21 KUBE dari kelompok masih aktif berjumlah 21 KUBE pada tahun 2019.

Bubarnya kelompok ini selain disebabkan dari kurangnya konsisten anggota kelompok usaha, kurangnya koordinasi dan komunikasi, kurangnya inovasi yang masih kurang karena tingkat pendidikan mereka masih rendah, pendampingan yang kurang merata, kurangnya sosialisasi dan pelatihan. Hal ini yang melatarbelakangi kenapa KUBE yang ada di Kecamatan Batu, Kota Batu berkurang dan dianggap dalam pelaksanaannya tidak efektif.

Dengan adanya KUBE ini diharapkan dapat meningkatkan kesejahteraan sosial kelompok miskin agar tercukupinya kebutuhan sehari-hari, dapat meningkatkan pendapatan keluarga, meningkatkan pengetahuan, serta meningkatkan derajat kesehatanya. Tetapi dalam pelaksanaan dari KUBE di Kota Batu bisa dilihat adanya tidak kesesuaianya dari beberapa pelaksanaan dengan tujuh aspek yang sudah di tentukan dalam pelaksanaan KUBE seperti kurangnya jumlah pendamping sehingga proses pendampingan kurang merata, pelaksanaan kegiatan sosialisasi dan pelatihan yang kurang diberikan kepada masyarakat yang tergabung dalam KUBE, ketidaksesuan jenis usaha yang dijalankan karena usaha yang dijalankan dalam berproduksi selalu berganti-ganti akibatnya bantuan modal yang didapatkan tersebut tidak sesuai dengan jenis usaha yang dijalankan. Ini menjadi sebuah hal yang memicu terjadinya banyak kelompok usaha yang sudah tidak berjalan dan tidak bertahan.

Di Kecamatan Batu sendiri sampai tahun 2019 ada sekitar 21 KUBE yang masih aktif dalam berproduksi dan ada sekitar 21 KUBE yang sudah tidak aktif. Berbagai cara dilakukan oleh Dinas Sosial dan para pendamping KUBE agar program 
ini tetap berjalan dan sesuai dengan kriteria pencapain keberhasilan yang diinginkan. Dalam penelitian ini nantinya akan dilihat bagaiaman evaluasi dari program KUBE yang ada di Kecamatan Batu sesuai dengan teori evaluasi William N.Dunn (Dunn, 2003) yang memiliki 6 kriteria yaitu: Efektifitas, Efisiensi, Kecukupan, Perataan, Responsivitas, dan Ketepatan.

Di Indonesia kajian tentang Kube telah dilakukan banyak peneliti. Misalnya kajian (Sitepu, 2016) yang melihat program baru ini belum optimal karena bermasalah pada manajemen pelaksanaan program mulai dari perencanaan, pengorganisasian, pengarahan dan pengendalian yang masih lemah. Hal ini juga ditentukan karena minimnya kapasitas masyarakat sebagai penerima dan pelaksana KUBE seperti temuan (Marhadi, 2017, Hiariey \& Romeron, 2017, Soviati, Fakhruddin, \& Ilyas, 2017). Kapasitas tersebut salah satunya soal minimnya kemampuan berwirasusahawa bagi masyarakat dalam program KUBE seperti temuan (Sariningsih, 2017).

Disisi lain ada beberapa cerita sukses tentang pelaksanaan KUBE. Temuan (Sabarisman, 2012) melihat kunci keberhasil melakukan perubahan sosial di masyarakat melalui KUBE di masyarakat desa Sayang Sandubaya Kota Mataram karena kuatnya budaya demokratisasi kelompok (musyawarah dalam pengambilan keputusan) dan modal sosial komunitas yang tinggi. Khusus faktor terakhir (modal sosial) membuat KUBE menjadi program pengentasan masalah ekonomi keluarga dimana didalamnya terjadi: proses belajar sosial, saling interaksi, saling membantu dalam mengatasi permasalahan sosial ekonomi sesama anggota (Muhtar, 2016) Selain kapasitas awal yang memang kuat dalam diri masyarakat, keberhasilan KUBE juga ditentukan oleh peran fasilitatif kelompok pendamping melalui pendekatan personal yang berkelanjutan seperti temuan di Kota Ambon (Nanlohy, Mulyana, \& Darwis, 2019). Selain itu keberhasilan KUBE seperti yang terjadi KUBE Mekarsari, Kota Bontang Kalimantan Timur karena mampu memberdayakan perempuan sebagai pengelola ekonomi keluarga (Irmawan, 2020).

Penelitian ini mengambil sudut pandang yang berbeda. Pertama, dengan menggunakan teori Evaluasi willian Dunn. Kedua, meletekan Kota Batu sebagai lokus penelitian dimana sampai sejauh ini melalui penelusuran yang penulis lakukan belum pernah dilakukan.

\section{METODE PENELITIAN}

Penelitian ini menggunakan penelitian jenis deskriptif, sebuah jenis penelitian yang memiliki suatu tujuan tertentu dalam menyusun secara sistematis 
serta tuntas mengan menggambarkan keadaan dari permasalahan atau problematika (Poerwanti, 1998). Metode yang digunakan oleh peneliti yaitu bersifat kualitatif. Lokasi penelitian ini dilakukan di Dinas Sosial Kota Batu. Subyek penelitian dalam penelitian ini adalah, Kepala Dinas Sosial Kota Batu, Kepala Seksi Pemberdayaan Fakir Miskin dan Keluarga Rentan, Pendamping KUBE Kecamatan Batu 1 orang, Pengurus KUBE Mawar 1 orang, Pengurus KUBE Harapan Kita 1 orang, Pengurus KUBE Berlian Bersinar 1 orang.

Sumber data yang digunakan dalam penelitian ini ada dua jenis yaitu data primer dan data sekunder. Data primer merupakan data yang didapatkan oleh peneliti yang dilakukakn secara langsung. Data primer dalam penelitian ini dilakukan dengan cara wawancara langsung kepada informan yang mengetahui segala hal yang terkait dengan Evaluasi Program Kelompok Usaha Bersama (KUBE) di Kecamatan Batu, Kota Batu yaitu Ibu Retno Probowati S.Sos selaku Kasi Pemberdayaan Fakir Miskin dan Keluarga Rentan Dinas Sosial Kota Batu, Pendamping KUBE Kecamatan Batu, serta Pengurus KUBE Mawar, KUBE Harapan Kita, serta KUBE Berlian Bersinar Bahasan peneliti yang juga dilengkapi catatan tertulis atau menggunakan alat rekam seperti handphone serta tape recorder.

Data sekunder merupakan data yang sudah didapatkan peneliti dari sumber yang sudah ada. Data tersebut didapatkan baik secara langsung atau pun data-data yang diperoleh melalui akses internet, jurnal, buku, serta hasil dari penelitian-penelitian terdahulu. Referensi tersebut digunakan sebagai bahan penelitian serta digunakan pegangan dalam melihat penelitian terdahulu dengan pembahasan yang masih sama. Teknik pengumpulan data dengan cara observasi, wawancara, dan dokumentasi. Teknik analisis data yang digunakan reduksi data, penyajian data, serta penarikan kesimpulan.

\section{HASIL DAN PEMBAHASAN}

Pada bagian ini penulis melakukan elaborasi untuk mengevalusi pelaksanaan KUBE di Kota Batu dengan menggunakan teori William Dunn dengan enam kriteria; Efektifitas, Efisiensi, Kecukupan, Perataan, Responsivitas, dan Ketepatan.

Efektifitas Program KUBE di Kecamatan Batu, Kota Batu

Efektifitas pada dasarnya sering digunakan dalam menentukan suatu keberhasilan dari program-program yang dilaksanakan. Efektifitas sendiri dapat diartkan sebagai pengukuran dari 
keberhasilan dalam pencapaian tujuan serta sasaran yanag telah ditentukan. Tingkat keberhasilan dari pelaksanaan program Kelompok Usaha Bersama (KUBE) yang ada di Kecamatan Batu sendiri dapat dilihat dari beberapa kelompok usaha yang berproduksi dengan sangat produktif ada juga kelompok usaha yang dalam perjalanananya juga belum mencapai tingkat produksi yang baik. Wawancara yang dilakukan dengan Koordinator pendamping KUBE yang ada di Kota Batu menyebutkan jika tingkat keberhasilan KUBE bisa dilihat dari apakah usaha yang dilakukan oleh pelaku usaha KUBE dapat berjalan dengan baik dan terus melakukan produksi sehingga dengan melakukan kegiatan produksi akan menambah pendapatan dari Kelompok Usaha Bersama tersebut.

Dari hasil penelitian yang dilakukan Ada beberapa KUBE dalam satu kelompok yang seharusnya harus berisi 10 anggota kelompok tersebut malah hanya berisi kurang dari 10. Kurangnya anggota kelompok tersebut dipengaruhi dari kurangnya tingkat kesadaran dan konsisten masing-masing anggota yang masih rendah. Terbukti dari anggota yang tidak aktif ada sekitar 3 sampai 5 orang yang dalam setiap produksinya bisa dikatakan hanya numpang nama dan tidak terlibat dalam kegiatan produksi secara langsung.
Jika dalam KUBE tidak genap 10 anggota maka tuposi yang sebelumnya sudah dibagi sesuai dengan kemampuan masing-masing anggota akan tidak akan berjalan dengan baik. Nantinya ada beberapa anggota kelompok yang akan menanggung resikonya sepert work twice. Jika ini terjadi terus menerus maka lama kelamaaan juga akan tidak efektif dan akan mempengaruhi tingkat produksi mereka. Pentingnya pendamping kelompok juga berperan penting dalam menyelesaikan masalahan tersebut.

Kendala yang lain juga terlihat dari beberapa anggota kelompok juga masih belum bisa dalam menggunakan media komunikasi dengan baik sehingga jika ada kegiatan yang mendadak mereka akan kebingunan sendiri. Produktifitas penjualannya juga tidak semua KUBE setiap hari bisa dilakukakn. Kegiatan monitoring dan evaluasi ini menjadi salah satu cara untuk menyelesaikan persoalan kelompok tersebut. Ada beberapa KUBE yang menerima pesananan setiap hari, mingguan, bulanan bahkan hanya dapat produksi jika ada pesanana saja.

Jika dilihat dari tingkat keberhasilan serta pencapaian target yang diinginkan KUBE di Kecamatan Batu masih belum bisa dikatakan berhasil dan belum efektif karena dari pelaksanaan KUBE yang ada di Kecamatan Batu sampai dengan tahun 
2019 ada sekitar 21 KUBE yang masih aktif dan ada 21 KUBE yang sudah tidak aktif dalam berproduksi.

Dinas Sosial Kota Batu juga bekerja sama dengan Dinas Perindstrian dan Pergadangan (DISPERINDAG) Kota Batu dalam perizianan labelisasinya. Ini sudah dilakukan mulai tahun 2018, agar barang produksi yang sudah dibuat oleh KUBE Kota Batu dapat dipasarkan secara meluas seperti Toko Oleh-oleh bahkan di supermarket. Dengan labelisasi yang diberikan dari DISPERINDAG tersebuat juga akan dapat menambah nilai jual dipasaran. Selain bekerja sama dengan DISPERINDAG, Juga bekerja sama dengan Dinas Kesehatan Kota Batu. Kerja sama ini dilakukan untuk memberikan izin Pangan Industri Rumah Tangga (PIRT) yang dikeluarkan oleh Dinas Kesehatan Kota Batu. Dengan dikeluarkan nya PIRT ini juga dapat menjamin jika produk yang diproduksi dari KUBE tersebut aman dikonsumsi dan layak untuk dipasarkan.

Berdasarkan konsep efektifitas dari William N. Dunn dari pelaksanaan program KUBE yang ada di Kota Batu ini dikatakan belum efektif karena jika dilihat dilapangan ada beberapa anggota dalam satu kelompok usaha yang tidak aktif dalam proses produksi. Ketidakatifan ini dapat menyebabkan kurang maksimalnya hasil yang didapatkan kelompok tersebut. Jika seharusnya dalam satu kelompok sudah dibagi tupoksi masing-masing maka, akan terjadi double job juga berdampak pada seberapa banyak hasil produksi yang didapatkan. Contoh kasus yang terjadi pada salah satu KUBE yang ada di Kecamatan Batu mendapatkan pesananan yang cukup banyak, akan tetapi mereka tidak berani mengambil pesanana tersbut dikarenakan anggota kelompok mereka ada 3 sampai 5 orang yang tidak aktif dalam produksi. Kasus seperti itulah yang nantinya menyebabkan konsumen ragu untuk memesan kembali produk ke kelompok usaha tersebut. Sehingga akan berdampak buruk terhadap kelangsungan KUBE ke depanya.

Tidak hanya itu saja hal lain yang ditemukan seperti kegiatan produktifitas penjualan yang tidak setiap hari produksi menyebabkan mereka menganggur. Ini terjadi karena KUBE yang ada di Kecamatan Batu tidak semuanya sama. Ada yang melakukan produksi setiap hari, mingguan, bulanan, bahkan saat ada pesanan saja. Karena kebanyakan anggota KUBE ini tidak semuanya bekerja, mengakibatkan mereka tidak memiliki pemasukan keuangan untuk kebutuhan sehari-hari. KUBE yang hanya berproduksi saat ada pesanan saja inilah yang paling dikhawatirkan oleh Dinas Sosial Kota Batu serta pendamping kelompok, yang dimana jika ini terjadi terus menerus menyebabkan mereka tidak aktif berproduksi selamanya, 
komposisi bahan yang digunakan dalam produksi tidak sama seperti sebelumnya, serta mereka juga akan kehilangan konsumen.

\section{Efisiensi Pelaksanaan Program KUBE di Kecamatan Batu, Kota Batu}

Efisisensi dapat diartikan sebagai suatu usaha yang dilakukan dapat mencapai hasil yang diinginkan secara maksimal. Tanpa harus membuang banyak waktu serta biaya. Efisiensi juga merupakan salah satu usaha yang dapat dikerjakan agar mencapai tingkat pencapaian yang diingnkan. Namun harus memperhatikan apa saja yang digunakan agar kebijakan yang dibuat tersebut dapat dikerjakan dan dilaksanakan dengan baik.

Permasalahan KUBE yang ada di Kecamatan Batu yang ditemukan adalah kelompok sering mengeluh terkait dengan bagaimana cara memutar dana yang digunaakan untuk produksi. Mereka selalu kebingungan jika ada bahan baku yang dibelinya melonjak tinggi sesuai dengan harga pasar. Jika hasil yang didapatkan sedikit ini juga menjadi ancaman sendiri bagi kelompok usaha untuk terus melakukan produksi. Mereka kadang juga kebingungan mensiasati kurang sinkronnya antara modal dan hasil yang didapatkan.

Untuk pengelolaan dana dari kelompok KUBE itu sendiri masih belum bisa dikatakan baik. Peran pendamping dan dari Dinas Sosial Kota Batu sendiri selalu terus melakukan Kegiatan seperti monitoring dan evaluasi harus sering dilakukan setiap untuk mengetahui berbagai kendala salah satunya terkait dengan pengelolaan anggran kelompok usaha.

Dinas Sosial Kota Batu dan pendamping terus melakukan inovasi untuk terus membantu KUBE yang ada di Kecamatan Batu terus berjalan dengan baik agar mereka dapat memperbaiki kualitas pendapatan sehingga dapat merasakan hasil dari program KUBE ini. Pada era saat ini, banyak dari masyarakat berfikir apapun harus dilakukan secara efisien apalagi banyak juga yang menggunakan smartphone pada saat ini. Itu juga menjadi salah satu alasan mengapa KUBE yang ada di Kecamatan Batu diajarkan untuk memasarkan produknya secara online melalui media sosial. Ini akan mempermudah mereka dalam mengenalkan produksi yang mereka buat. Kegiatan ini juga menjadi tantangan baru Dinas Sosial untuk melakukan inovasi terkait dengan pelatihan pemasaran secara online. Tetapi pelatihan pemasaran online yang diberikan oleh Dinas Sosial Kota Batu dirasa kurang puas bagi anggota KUBE yang mengikuti pelatihan. Dimana pelatihan yang diadakan belum fokus terhadap tata cara pemasaran secara online, 
melainkan hanya diajarkan bagaimana membuka internet saja. Jika pelatihan yang diberikan hanya sebatas membuka internet saja maka kegiatan pelatihan seperti ini hanya akan sia-sia dan tidak efisien. Kendala lainya banyak sekali anggota KUBE yang sudah lanjut usia sehingga daya tangkap terkait dengan penggunaan sosial media juga masih minim. Apalagi ada juga anggota KUBE yang tidak memiliki smathphone yang menyebabkan mereka tidak bisa mengikuti pelatihan tersebut.

Antara pendamping dan Dinas Sosial Kota Batu sebaiknya lebih memperhatihan terkait pemasaran produk secara online tersebut, mengingat banyak sekali kendala yang ditemukan. Mengingat zaman sekarang ini banyak sekali masyarakat yang selalu berbelanja secara online guna mempersingkat waktu dan dengan memasarkan seacara online juga banyak sekali keuntungan yang akan didaptkan oleh kelompok usaha jika menggunakannya dengan tepat.

\section{Kecukupan program KUBE dalam memecahkan masalah kemiskinan di Kecamatan Batu, Kota Batu}

Kecukupan berkenaan dengan seberapa jauh dari tingkat efektivitas dengan mencukupi semua kebutuhan nilai dengan kesempatan yang akan menumbuhkan adanya suatu masalah. Kecukupan ini juga masih berhubungan dengan efektivitas mengukur juga serta memprediksi seberapa besar alternatif yang akan digunakan dalam memenuhi segala kebutuhan, nilai, dan juga kesempatan dalam menyelesaikan suatu permasalahan yang terjadi.

Dalam pelaksanaannya program Kelompok Usaha Bersama (KUBE) yang ada di Kecamatan Batu ternyata program KUBE ini dirasa belum mencukupi kebutuhan anggota KUBE dan juga anggota KUBE pun belum merasa puas dari program ini. Karena mereka juga ada yang hanya memasarkan barang produksinya tidak secara luas, sehingga untuk keuntungan pendapatan juga belum mereka rasakan. Karena jika semakin banyak produk yang mereka pasarkan secara luas maka juga semakin banyak juga keuntungan yang akan mereka dapatkan. Sebaliknya jika hanya dipasarkan pada 1 atau 2 warung saja hasilnya pun juga tidak seberapa didapatkan.

\section{Pemerataan Bantuan yang diterima oleh KUBE di Kecamatan Batu, Kota Batu}

Perataan masih memiliki hubungan dengan rasionalitas legal dan sosial serta menunjukkan pada distribusi akibat serta usaha antara kelompok yang berbeda 
dalam masyarakat. Program Kelompok Usaha Bersama (KUBE) ini untuk perataan manfaat yang diterima belum dirasakan dalam kelompok mereka. Seperti KUBE harapan kita yang memproduksi krupuk bawang hanya memasarkan produknya satu inggu sekali saja. Apalagi dalam anggota KUBE tersebut banyak juga yang tidak memiliki pekerjaan atau hanya sebagai ibu rumah tangga saja. Otomatis mereka mendapatkan tambahan untuk keperluan rumah tangganya dari program ini selain dari pekerjaan suami mereka.

Dari KUBE Mawar yang memproduksi sari buah pun juga belum merasakan terkait dengan pemerataan hasil dari produksi mereka. Saat pembagian hasil mereka milih untuk kerja dari pada ikut bergabung dengan KUBE, karena hasil yang didapatkan masih kecil sehingga belum bisa mencukupi kebutuhan. Apalgi di KUBE ini banyak anggota yang sudah tidak aktif. Maka dari itu harus ada jalan keluar untuk menyelesaikan masalah seperti ini.

Pendapat yang berbeda dari KUBE Berlian Bersinar karena, mereka merasakan manfaatnya dari belum bisa membuat telor puyuh asin sekarang menjadi bisa mulai dari bahan apa saja yang dibutuhkan, proses membuat telur asin yang baik, sampai dengan proses penjualan. Mereka juga sudah menerima hasil yang didapatkan sesuai dengan hadir atau tidaknya saat berproduksi. Dengan menggunakan sistem absen pada KUBE Berlian Bersinar ini maka akan mempermudah ketua kelompok dalam mengontrol anggotanya. Ketua kelompok pun nantinya juga dapat mengetahui siapa yang aktif saat produksi dan siapa yang kurang berpartisipasi. Dalam proses pembagian hasil pun nantinya juga akan jauh lebih adil karena sebelum pambagian hasil akan dilihat presensi pada saat itu.

\section{Responsivitas Dinas Sosial Kota Batu dan Pendampingan program KUBE di} Kecamatan Batu, Kota Batu

Responsivitas diartikan sebagai respon dari suatu aktivitas terhadap sasaran atas penerapan dari suatu kebijakan. Dengan kata lain kepuasan yang dapat dirasakan baik itu dari pihak yang memberikan pelayanan ataupun bagi penerima layanan tersebut. Responsivitas juga berkenaan dengan seberapa jauh kebijakan dapat merasakan, kebutuhan, preferensi, atau nilai kelompok-kelompok masyarakat tertentu.

Aspek responsivitas dari pelaksanaan KUBE yang ada di Kecamatan Batu dikatakan masih kurang karena dari Pendamping belum melakukan monitoring dan evaluasi yang berlangsung setiap sebulan sekali dengan rutin. Jika pelaksaaan ini bisa ditambah tidak hanya 
sekali maka akan lebih baik dan intensif. Karena mengingat banyak anggota KUBE yang memiliki pendidikan yang rendah dan kurangnya pengalaman. Maka harus sesering mungkin agar mereka dapat lebih paham dengan kegiatan yang mereka lakukan. Mulai tahun 2015 sampai dengan tahun 2019 KUBE yang ada di Kecamatan Batu yang sudah tidak aktif sudah mencapai 21 kelompok.

Ketidakaktifan KUBE disebabkan beberapa hal seperti kurang konsistennya anggota kelompok tersebut, kurang koordinasi dan komunikasi antara anggota satu dengan yang lain, kurangnya sosialisasi dan pelatihan, serta kurangnya pendampingan yang disebabkan karena jumlah pendamping yang ada di Kota Batu hanya memiliki 2 pendamping kelompok saja.

Untuk kegiatan monitoring dan evalusi juga belum dilakukan secara rutin setiap bulanya. Dilihat dari tiga pendapat yang diungkapkan oleh anggota KUBE yang ada di Kecamatan Batu, mereka juga mengeluhkan terkait dengan pendampingan dalam hal monef yang tidak dilakukan setiap bulannya. Padahal mereka juga butuh pendampingan dan tetap muka dengan pendamping secara langsung agar pendamping tahu apa yang mereka butuhkan.
Kegiatan monef juga penting dilakukan antar pendamping dan anggota KUBE untuk membicarakan kegiatan serta perkembangan kelompok mereka, supaya cepat berhasil dan berkembang sesuai dengan yang mereka inginkan.

Dengan ketidakdisiplinan dalam melaksanakan kegiatan monitoring dan evaluasi atau monef dari program KUBE merupakan bantuk tidak konsistennya Pemerintah Kota Batu dalam pelaksanaan program ini. Tidak dilakukanya kegiatan monef secara rutin oleh pendamping atau Dinas Sosial Kota Batu membuat mereka tidak mengetahui permasalahan apa saja yang terjadi dalam suatu kelompok. Padahal jika dilihat dari konsisiten pelaksanaan program Kelompok Usaha Bersama ini, Dinas Sosial Kota Batu dan pendamping kelompok menaruh perhatian penuh dalam kegiatan monitoring dan evaluasi.

Ketepatan (Pencapaian hasil dari program KUBE di Kecamatan Batu,

\section{Kota Batu)}

Pencapaian ini akan lebih mengarah kepada nilai atau harga dari suatu tujuan dari program dan sama kuatnya dengan asumsi yang akan melandasi dari tujuantujuan tersebut. Kriteria kelayakan dihubungkan dengan rasionalitas subtansif. Karena dari kritreria ini akan dapat 
menyangkut sari suatu subtansi tujuan untuk merealisasi tujuan tersebut. Dari pelaksanaan KUBE yang ada di Kecamatan Batu, Kota Batu bisa dikatakan tepat jika ketepatan dalam pelaksanaan program ini mencapai tujuan yang diinginkan.
Berikut ini merupakan tampilan sajian tabel indikator penilaian untuk melihat bagaimana pelaksanaan program KUBE di Kecamatan Batu Kota Batu.

Tabel 1.

Pencapaian hasil Program Kelompok Usaha Bersama (KUBE) di Kecamatan Batu Kota Batu

\begin{tabular}{|c|c|c|c|}
\hline Indikator Keberhasilan & Deskripsi & $\begin{array}{c}\text { Bobot } \\
\text { Target } \\
(\%)\end{array}$ & $\begin{array}{c}\text { Target } \\
\text { Pencapaian } \\
\text { Kinerja } \\
(\%) \\
\end{array}$ \\
\hline $\begin{array}{l}\text { Meningkatnya taraf kesejahteraan } \\
\text { keluarga masyarakat miskin }\end{array}$ & $\begin{array}{l}\text { Meningkatnya penghasilan } \\
\text { yang didapatkan }\end{array}$ & $40 \%$ & $100 \%$ \\
\hline $\begin{array}{l}\text { Mewujudkan kemandirian terkait } \\
\text { dengan usaha, sosial, ekonomi } \\
\text { keluarga masyarakat miskin }\end{array}$ & $\begin{array}{l}\text { Terbentuknya KUBE yang } \\
\text { yang terorganisir dengan } \\
\text { baik }\end{array}$ & $50 \%$ & $100 \%$ \\
\hline $\begin{array}{l}\text { Meningkatkan aksebilitas keluarga } \\
\text { masyarakat miskin terhadap } \\
\text { pelayanan sosial dsar serta sistem } \\
\text { jaminan kesejahteraan sosial }\end{array}$ & $\begin{array}{l}\text { Meningkatkan akses } \\
\text { masyarakat miskin melalui } \\
\text { program KUBE }\end{array}$ & $80 \%$ & $100 \%$ \\
\hline $\begin{array}{l}\text { Peningkatan jumlah asset } \\
\text { individual masyarakat miskin } \\
\text { anggota KUBE. }\end{array}$ & $\begin{array}{l}\text { Adanya dana yang disimpan } \\
\text { sebagai tabungan }\end{array}$ & $40 \%$ & $100 \%$ \\
\hline $\begin{array}{l}\text { Meningkatkan kepedulian dan } \\
\text { tanggungjawab sosial masyarakat } \\
\text { dan sunia usaha dalam program } \\
\text { pemberdayaan masyarakat miskin. }\end{array}$ & $\begin{array}{l}\text { Terwujudnya Kerjasama } \\
\text { dan tanggungjawab dalam } \\
\text { pengembangan usaha } \\
\text { melalui program KUBE }\end{array}$ & $80 \%$ & $100 \%$ \\
\hline $\begin{array}{l}\text { Meningkatkan ketahanan sosial } \\
\text { masyarakat dalam memberdayakan } \\
\text { masyarakat miskin. }\end{array}$ & $\begin{array}{l}\text { Meningkatkan partisipasi } \\
\text { masyarakat dalam } \\
\text { organisasi sosial lokal serta } \\
\text { berperan aktif dalam } \\
\text { pemberdayaan masyarakat } \\
\text { miskin }\end{array}$ & $70 \%$ & $100 \%$ \\
\hline $\begin{array}{l}\text { Meningkatkan kualitas manajemen } \\
\text { pelayanan kesejahteraan sosial } \\
\text { terhadap keluarga masyarakat } \\
\text { miskin. }\end{array}$ & $\begin{array}{l}\text { Meningkatnya kualitas } \\
\text { sumber daya manusia, } \\
\text { pekerja sosial dan } \\
\text { pendampingan sosial lokal. }\end{array}$ & $80 \%$ & $100 \%$ \\
\hline
\end{tabular}

Sumber : Diolah Oleh Penulis 2019 
Berdasarkan dari indikator penilaian pencapaian hasil program Kelompok Usaha Bersama (KUBE) yang ada di Kecamatan Batu, Kota Batu pada sub peningkatan taraf kesejahteraan keluaraga masyarakat miskin memiliki bobot target $40 \%$ dari total target pencapaian kinerja. Karena belum sepenuhnya penghasilan yang didapatkan oleh anggota KUBE mampu mencukupi kebutuhan sehari-hari meraka. Hal ini dikarenakan hasil yang mereka dapatkan juga harus dibagi kepada anggota kelompok yang lain. Apalagi dari pelaksanaan produksi tidak semua KUBE berproduksi setiap hari, ada yang harian, ada yang mingguan, bahkan ada yang hanya menerima jika ada pesanan saja.

Pada sub indikator mewujudkan kemandirian usaha, sosial, ekonomi keluarga masyarakat miskin memiliki bobot target $50 \%$ dari total target pencapaian kinerja. Hal ini disebabkan karena masih banyaknya KUBE yang ada di Kecamatan Batu ini sudah tidak aktif dan akhirnya bubar. Jumlah KUBE yang masih aktif ada 21 kelompok dan yang sudah tidak aktif ada 21 kelompok. Jadi jumlah KUBE yang tidak aktif di Kecamatan Batu adalah yang paling banyak jika dibandingan dengan kecamatan seperti Kecamatan Junrejo, dan Kecamatan Bumiaji.
Sub Meningkatkan aksebilitas keluarga masyarakat miskin terhadap pelayanan sosial dasar dan sistem jaminan kesejahteraan sosial memiliki bobot target $80 \%$ dari target pencapain kinerja. Pada sub ini kebutuhan pelayanan sosial dasar seperti rumah yang layak huni dan sehat, pendidikan dasar, serta Kesehatan sudah terpenuhi. Tetapi terkait dengan lapangan pekerjaan masih banyak anggota KUBE yang menganggur dan hanya mengandalkan produksi KUBE saja. Sehingga masih belum bisa mencukupi kebutuhan sehari-hari keluarganya.

Selanjutnya pada sub peningkatan jumlah aset individual masyarakat miskin anggota KUBE memiliki bobot target $40 \%$ dari target pencapaian kinerja. Karena hasil yang didapatkan dari produksi KUBE saja bisa dikatakan pas pasan. Sehingga masih belum ada dana tabungan yang digunakan untuk asset pribadi.

Pada sub meningkatkan kepedulian dan tanggungjawab sosial masyarakat dan dunia usaha dalam program pemberdayaan masyarakat miskin memiliki bobot $80 \%$ dari target pencapaian kinerja. Alasanya untuk Kerjasama yang sudah terjalin antara anggota KUBE dengan pihak swasta sudah baik, tetapi terkadang anggota KUBE ini masih belum konsisten dengan apa yang mereka buat. Seperti rasa, bentuk, ukuran yang ada dalam produk makanan/kerajinan 
tangan berbeda. Sehingga menyebabkan orang yang memesan tersebut mengeluh.

Pada sub meningkatkan ketahanan sosial masyarakat dalam memberdayakan masyarakat miskin memiliki bobot target $70 \%$ dari target pencapain kinerja. Karena masih banyak anggota KUBE yang kurang aktif dalam kelompok mereka saat produksi menyebabkan double job sehingga hasil yang didaptkan kurang maksimal. Kurangnya sosialisasi dan pelatihan yang didapatkan oleh anggota KUBE.

Terakhir pada sub meningkatkan kualitas manajemen pelayanan kesejahteraan sosial terhadap keluarga masyarakat miskin memiliki bobot $80 \%$ dari target pencapaian kinerja. Terkait dengan pendampingan yang diberikan oleh pendamping kelompok masih belum merata sehingga manajemen yang ada dalam kelompok KUBE belum sepenuhnya sfektif dan efisien.

Pencapaian dalam pelaksanaan KUBE salah satunya dapat dilihat dari berhasilnya masyarakat miskin yang tergabung dalam KUBE melakukan graduasi mandiri. Artinya para anggota KUBE yang ada di Kecamatan Batu, Kota Batu sudah bisa lepas dari bantuan sosial yang mereka terima selama ini. Lepasnya bantuan yang mereka terima ini, mereka merasa sudah merasa cukup untuk memenuhi segala kebutuhan sehariharinya.

Dari penelitian yang dilakukan di Kecamatan Batu sendiri masih belum banyak masyarakat yang tergabung dalam KUBE yang melakukan graduasi mandiri. Mereka masih mengandalkan bantuan sosial yang mereka terima. Para anggota KUBE ini juga masih enggan jika mereka melepaskan bantuan tersebut.

Pada tahun 2019 kemarin ada sekitar 18 Kelompok Usaha Bersama yang menerima bantuan sarana dan prasarana tersebut. 18 kelompok ini belum menerima bantuan pada tahun sebelumnya dan baru menerima pada tahun 2019. Kecamatan Batu ada sebanyak 4 KUBE menerima bantuan sarana dan prasarana. Pada kegiatan penyaluran bantuan juga dilanjutkan dengan kegiatan sosialisasi dan pelatihan. pada tahun 2019 juga kegiatan sosialisasi hanya dilakukan sekali saja karena dana yang digunakan mengalami keterlambatan sehingga menyebabkan sosialisasi dan pelatihan dilakukan setahun sekali saja. Ini juga belum bisa dikatakan efektif jika pelatihan tidak dilakukan secara teratur.

\section{Refeksi Teoritis}

Dengan menggunakan teori William Dunn ditemukan bahwa program KUBE di Kota Batu belum efektif seperti ketika 
diinisiasi; Penanggulangan Kemiskinan dengan peningkatan kemampuan berusaha. Fakta ini mengulang-ulang kelamahan paradigma implementasi kebijakan di Indonesia yang kuat di konsep namun lemah di implementasi. Birokrasi teknis yang dalam hal ini Dinasi Sosial Kota Batu belum optimal dalam melakukan fungsi pendampingan-sesuatu yang sangat vital dalam transformasi pengentasan kemiskinan.

Masyarakat sebagai penerima kelompok powerless diharapkan dapat naik kelas menjadi powerwull (jangka panjang) dengan hadirnya Program KUBE. Dengan meminjam teori evaluasi Wiliam Dunn yang bertujuan melihat seberapa jauh kebijakan dan implementasi KUBE mendekati tujuan yang ditetapkan terlihat konsekuensi yang diharapkan berupa peningkatan pendapatan ekonomi peserta belum optimal tercapai. Evalusi yang dilakukan disini memberikan penilaian terhadap implementasi program KUBE di Kota Batu yang dinyatakan belum maksimal.

Evaluasi berarti kinerja kebijakan yang dapat diukur melalui kapabilitas (kinerja) birokrasi teknis dan penerima sasaran. Birokrasi teknis yang dalam hal ini adalah Dinas Sosial sebagai eksekutor program dekosentrasi dari Kementrian Sosial ini belum melakukan kerja-kerja berkelanjutan dalam pendampingan dan evaluasi. Padahal masyarakat masih sangat kesulitan dalam teknis pelaksanaanya sehingga aktifitas pemantauan, evaluasi dan solusi dari Dinas Sosial mutlak dibutuhkan. Disisi lain masyarakat juga sudah perlu menaikan kapasitas pengetahuan secara mandiri tanpa harus selalu bergantung ke pemerintah. Daya jangkau pemerintah yang sangat terbatas memang bukan menjadi dalih minimnya kontiniutas dalam pendampingan program KUBE, namun masyarakat juga perlu belajar secara serius pada program yang diberikan sehingga lebih dapat secara mandiri berkembang. Caranya dengan menjadi penerima yang aktif (mencari informasi di banyak sumber), tidak hanya pasif menunggu bimbingan teknis dari Dinas Sosial. Kunci semua ini adalah kualitas impelementasi program KUBE yang transformaif, kolaboratif dan transparan.

Evaluasi kebijakan dari Wiliam Dunn yang menjadi pisau analisis dalam melihat KUBE di Kota Batu sudah cukup representatif mengambarkan kelemahan dalam implementasi kebijakan KUBE. Dengan enam indikator evaluasi yang dirumuskan terekam jelas bagaimana kendala empiris yang terjadi dan celakanya menjadi kelemahan dasar yang selalui berulang di Indonesia. Ini tentu saja menjadi catatan penting buat eksekusi program-program pemberdayaan 
selanjutnya agar lebih efisien dan efektif dalam meningkatkan kesejahteraan masyarakat.

\section{KESIMPULAN}

Evaluasi kebijakan berguna dalam memberikan rekomendasi atas perbaikan kebijakan publik. Dari identifikasi masalah yang dilakukan dapat ditemukan alternatif penyelesaianya sehingga langkah tersebut dapat diprioritaskan selanjutnya. Dari penjelasan sebelumnya dengan menggunakan 6 (enam) indikator (kriteria0 evaluasi kebijakan William Dunn dapat disimpulkan bahwa Implementasi KUBE di kota Batu belum efektif. Pertama, kriteria efektifitas dari program KUBE yang ada di Kecamatan Batu ini masih belum efektif karena ada beberapa orang dalam kelompok mereka yang anggotanya tidak aktif dalam berproduksi. Sehingga menyebabkan kurang maksimalnya hasil yang didapatkan. Ada beberapa KUBE yang menerima pesanan satiap hari, mingguan, bulanan, bahkan hanya dapat produksi saat ada pesanana saja.

Kedua, terkait dengan kriteria efisieinsi pengeloaan dana dari kelompok KUBE masih belum bisa dikatakan baik karena seringkali mereka kebingungan dengan modal yang digunakan untuk membeli barang baku produksi. Dari hasil produksi yang dijual pun juga terkadang tidak habis, sehingga hasil yang didapatkan pun berkurang. Namun banyak sekali kendala yang ditemukan karena banyak juga anggota KUBE yang tidak memiliki smartphone sebagai salah satu hal yang wajib dimiliki dalam melakukan pelatihan pemasaran secara online. Ketiga, kriteria kecukupan ini berhubungan dengan efektivitas mengukur serta memprediksi seberapa besar alternatif yang digunakan untuk menyelesaikan suatu permasalahan yang terjadi. Yang ditemukan hasil yang didapatkan dari program KUBE ini masih belum bisa mencukupi kebutuhan sehari hari mereka.

Keempat, kriteria pemerataan yang berkaitan dengan segi manfaat dari program KUBE ini sudah dirasakan oleh anggota. Dimana yang semula belum bisa membuat/mengelola suatu bahan sekarang bisa membuat sendiri. Namun, hasilnya belum bisa mencukupi kebutuhan seharihari mereka. Kelima, pada kriteria responsifitas yang berkenaan sebagai respon dari suatu aktivitas terhadap penerapan dari suatu kebijakan. Yang dirasakan oleh anggota KUBE adalah kurangnya pendampingan yang diberikan oleh pendamping kelompok. Karena kegitan monitoring dan evaluasi belum sepenuhnya dilakukan secara rutin ke kelompok KUBE, sehingga banyak sekali permasalahan kelompok yang terjadi. 
Keenam, kriteria ketepatan dari pelaksanaan program KUBE di Kecamatan Batu dikatakan belum tepat. Karena KUBE yang ada di Kecamatan Batu masih belum banyak yang melakukan graduasi mandiri. Untuk proses penyaluran bantuan yang diberikan oleh KEMENSOS RI udah tepat dengan apa yang dibutuhkan oleh anggota KUBE untuk kegiatan produksi mereka.

Dari evaluasi yang dilakukan target Dinas Sosial Kota Batu dalam program KUBE belum tercapai. Beberapa permasalahan dasar yang harus segera diselesaikan adalah minimny pelatihan bagi anggota KUBE, kurangnya pendampingan kelompok dan monitoring dan Evaluasi (Monev), serta kurangnya manajemen kelompok dalam menanggapi masalah yang terjadi.

\section{DAFTAR PUSTAKA}

Boone, K., \& Roets, G. (2018). Social Work, Participation, and Poverty. Journal of Social Work, O(0), 1-18. https://doi.org/10.1177/14680173187 60789

Chaudry, A., \& Wimer, C. (2016). Poverty is Not Just an Indicator: The Relationship Between Income, Poverty, and Child Well-Being. Academic Pediatrics, 16(3), S23-S29. https://doi.org/10.1016/j.acap.2015.12 .010

Dunn, W. (2003). Pengantar Analisis Kebijakan Publik (Edisi 2). Sleman: UGM Press.

Hadi, Krishno, Listiano Asworo, and Iradhad Taqwa Sihidi. (2020). "Inovasi Dialogis: Menuju
Transformasi Pelayanan Publik Yang Partisipatif (Kajian Sistem Pelayanan Malang Online)." Journal of Government and Civil Society 4(1):115-29.

http://dx.doi.org/10.31000/jgcs.v4i1.2438

Irmawan. (2020). Keberhasilan Kube Mekarsari dalam Meningkatkan Kesejahteraan Keluarga. Media Informasi Kesejahteraan Sosial, 44(1), 130-142. https://doi.org/10.31105/mipks.v44i1. 1954

Kwasi, A. (2017). Research in Economics Growth, Inequality, and Poverty Reduction in Developing Countries : Recent Global Evidence R. Research in Economics, 71, 306-336. https://doi.org/10.1016/j.rie.2016.05.0 05

Lilian Sarah Hiariey, N. R. R. (2017). Penguatan Kelompok Usaha Bersama (KUBE) Perikanan Tangkap (Studi Kasus Desa Latuhalat, Kota Ambon, Provinsi Maluku). Jurnal Matematika, Saint, dan Teknologi, 18(2), 120-129.

Marhadi, A. (2017). Profil Elektronik Warung Gotong Royong (E-Warong) KUBE PKH Sebagai Alternatif Penanggulangan Kemiskinan di Provinsi Sulawesi Tenggara. ETNOREFLIKA, 6(3), 183-200. https://doi.org/10.33772/etnoreflika.v $6 \mathrm{i} 3.487$

Muhtar, I. N. (2016). Potensi Modal Sosial Pada Kelompok Usaha Bersama Program Penanggulangan Kemiskinan. Sosio Informa, 2(2), 155-165. https://doi.org/10.33007/inf.v2i2.254

Nanlohy, B., Mulyana, N., \& Darwis, R. S. (2019). Dampak Peran Pendamping Terhadap Pengembangan Usaha dari Kube (Kelompok Usaha Bersama) di Kota Ambon. Jurnal Public Policy, 5(2), 83-97. https://doi.org/10.35308/jpp.v5i2.112 1

Poerwanti, E. (1998). Dimensi-Dimensi Riset Ilmiah. Malang:UMM Press. 
Ras, A. (2013). Pemberdayaan Masyarakat Sebagai Upaya Pengentasan Kemiskinan. Socius, 14, 56-63.

Sabarisman, M. (2012). Perubahan Sosial dalam Pemberdayaan Masyarakat Miskin Perkotaan"Pemberdayaan Melalui KUBE di Kelurahan Sayangsayang Kota Mataram." Sosiokonsepsia Vol., 17(03), 252-268. ttps://doi.org/10.33007/ska.v17i3.830

Sariningsih, Y. (2017). Entrepreneurial Culture of KUBE. Journal Sampurasun, 03(02), 69-81.

Sitepu, A. (2016). Analisis Efektifitas Kelompok Usaha Bersama Sebagai Instrumen Program Penanganan Fakir Miskin. Sosio Informa, 2(1), 53-68. https://doi.org/10.33007/inf.v2i1.212

Soviati, B. M., Fakhruddin, F., \& Ilyas, I. (2017). Pembinaan Anak Rentan Tindak Kriminal melalui KUBE pada Anak Binaan PSMP Antasena Magelang. Journal of Nonformal Education and Community Empowerment, 1(2), 128-136. https://doi.org/10.15294/pls.v1i2.1416 6

Sutter, C., Bruton, G. D., \& Chen, J. (2018). Entrepreneurship as A Solution to Extreme Poverty: A Review and Future Research Directions. Journal of Business Venturing, (May), 0-1. https://doi.org/10.1016/j.jbusvent.201 8.06.003

Widayanti, S. Y. M., \& Hidayatulloh, A. N. (2015). Kinerja Kelompok Usaha Bersama (KUBE) dalam Pengentasan Kemiskinan Business Group Program Performance on Poverty Elevation. Jurnal PKS, 14(2), 163-180.

Zhou, Y., Guo, L., \& Liu, Y. (2019). Land Use Policy Land Consolidation Boosting Poverty Alleviation in China: Theory and Practice. Land Use Policy, 82, 339-348. https://doi.org/10.1016/j.landusepol.2 018.12.024 